Pro Bono in Principle and in Practice 



\section{PRO BONO}

in

\section{PRINCI P LE}

and in

PRACTICE

Public Service and the Professions

\section{Deborah L. Rhode}

STANFORD LAW AND POLITICS

An imprint of Stanford University Press

Stanford, California 2005 


\begin{abstract}
Stanford University Press
Stanford, California

(C) 2005 by the Board of Trustees of the Leland Stanford Junior University. All rights reserved.

No part of this book may be reproduced or transmitted in any form or by any means, electronic or mechanical, including photocopying and recording, or in any information storage or retrieval system without the prior written permission of Stanford University Press.
\end{abstract}

Library of Congress Cataloging-in-Publication Data

Rhode, Deborah L.

Pro bono in principle and in practice : public service and the professions / Deborah L. Rhode.

p. $\mathrm{cm}$.

Includes bibliographical references and index.

ISBN 0-8047-5106-4 (cloth : acid-free paper) -

ISBN 0-8047-5107-2 (pbk. : acid-free paper)

1. Legal assistance to the poor-United States. I. Title.

KF336.R486 2005

$347.73^{\prime} 17-$ dc22

2005004365

Original Printing 2005

Last figure below indicates year of this printing:

$\begin{array}{llllllllll}14 & 13 & 12 & 11 & 10 & 09 & 08 & 07 & 06 & 05\end{array}$

Designed by James P. Brommer

Typeset in 10.5/15 Minion

Special discounts for bulk quantities of Stanford Law and Politics are available to corporations, professional associations, and other organizations. For details and discount information, contact the special sales department of Stanford University Press. Tel: (650) 736-1783, Fax: (650) 736-1784. 